\title{
Plant Existence as a Main Factor Affecting Water Availability in Deserts
}

\author{
Dr. Wail M. Omran \\ Associate Professor in Department of Soil Science, Faculty of Agriculture, Menofia University
}

\begin{abstract}
Deserts occupy about ninety percent of the area of Egypt. In deserts, water rarely exists, and is quickly lost if found. So, the most important parameters, to study, are soil water holding capacity (WHC) and plant available water (AW), which strongly affect and control irrigation interval and its requirement. Looking for soil with the highest WHC and AW to start with it, in reclamation, should reduce cultivation costs and increase water saving and agricultural production. A remarkable observation is the heterogeneity of deserts especially in their naturally grown or wild plants, which appear in some areas and disappear in other areas at the same location. The research is aiming to study the effect of the existence of wild plants on WHC and AW. To reach the research objective, field study was carried out in Eastern Egyptian desert. Soil samples were collected from plant covered areas and bare ones at different sites. The obtained results indicate significant improvement in both WHC and AW at plant covered areas. The study recommends starting with wild plants covered areas and conducts further studies of the special effects of specific plants to be cultivated in bare desert lands to improve their soil water status for the purpose of further reclamation.
\end{abstract}

Keywords: Desert - water holding capacity - available water - wild plants.

\section{Introduction}

Ninety percent of Egypt land area is desert (Yousef and Hegazi (2006)). Some studies indicate a wide plant diversity in Eeastern desert of Egypt (e.g. El-Amier and AbdulKader, 2015; Gomaa, 2012). Zdruli (2011) Stated that "the availability of fertile soil suitable for crop production in the region is quite limited. This is especially true in the Middle East. Monier Abd El-Ghani et al. (2011) compared all desert climbing plants in Egypt to those found in the deserts of other continents (specifi cally, the Australian, Sonoran, and Chihuahuan deserts) revealed the same dominant plant families.

The reclamation of desert is mandatory to face the growing population but it costs a lot in such poor lands especially because of their physical properties. In a study of Egyptian deserts reclamation, Hegazi et al. (2005) stated that "all the traditional farmers and the greater majority of the agricultural graduates have their experience background based on cultivation practices of the old alluvial fertile lands". In desert, water rarely exists, and is quickly lost if found. So, the most important parameters, among physical properties, are soil water holding capacity and plant available water. Such two parameters, strongly, affect and control irrigation interval and its requirement. Looking for soil with the highest water holding capacity (WHC) and available water (AW) to start with it, in reclamation, should reduce cultivation costs and increase water saving and agricultural production. A remarkable observation is the heterogeneity of deserts especially in their naturally grown or wild plants, which appear in some areas and disappear in other areas at the same location. The research is aiming to study the effect of the existence of wild plants on WHC and AW.

\section{Materials and Method}

Four sites at the north area of the eastern desert in Egypt were selected to collect soil samples. Total twenty four surface $(0-0.3 \mathrm{~m})$ soil samples were collected (i.e. 4 sites $\times 2$ locations at each site (plant covered and bare soil areas) $\times 3$ replicates). The samples were taken using soil auger. The represented samples were prepared and subjected to physical and chemical analysis. The Mechanical analysis was done by pipette method according to Klute (1986). WHC; FC and PWP were determined, for the purpose of evaluating soil water status. FC and PWP were measured using Pressure membrane method at 0.33 and 15 bars. Available water (AW) was estimated as the difference between soil water content at FC and PWP (Piper, 1947). Electrical conductivity (EC) of the saturated extract of the soil was determined by the method described by Black (1965). Soil pH was determined in soil to suspension (1:2.5 respectively) using $\mathrm{pH}$ meter (Black (1965)). Determination of $\mathrm{Na}^{+}$and $\mathrm{K}^{+}$was done using flam photometer apparatus according to the method described by Jackson (1964). $\mathrm{Ca}^{++}$and $\mathrm{Mg}^{++}$were determined by EDTA titration (Black (1965)). Determination of $\mathrm{CO}_{3}{ }^{--}$and $\mathrm{HCO}_{3}{ }^{-}$was done by titration according to the method described by Black (1965).

Determination of $\mathrm{Cl}^{-}$was done using $\mathrm{AgNO}_{3}$ according to the method described by Skoog et al. (1996). Determination of $\mathrm{SO}_{4}^{--}$was estimated by the difference between cations and anions (Page et al., 1982). Calcium carbonate content was determined by Calcimeter Black (1965)).

\section{Results and Discussion}

The north area of Egyptian eastern desert was selected because of its wide diversity of wild plants and ready to germinate seeds. El-Amier and AbdulKader (2015) studied the plant diversity of the northern area of eastern desert. Ninety five plant species were found. Gomaa (2012) conducted a study in the same location of eastern desert and found wide diversity of ready to germinate seeds. Moreover, the selected sites are relatively closed to Cairo and Suez which give it an economical priority in reclamation. The remarkable observation that there are bare areas and wild

\section{Volume 5 Issue 2, February 2016}




\section{International Journal of Science and Research (IJSR) \\ ISSN (Online): 2319-7064 \\ Index Copernicus Value (2013): 6.14 | Impact Factor (2014): 5.611}

plants covered areas at the same site for several years which may affect soil properties positively or negatively because of shoot and or root system of the grown plants. Soil physical analysis data of the bare and plant covered soils of the four studied sites are presented in Table 1

Table 1: Soil Physical Analysis of the bare and plant covered soil in the experimental studied sites

\begin{tabular}{|c|c|c|c|c|c|c|c|c|c|}
\hline \multirow{2}{*}{ Sites } & \multirow{2}{*}{$\begin{array}{c}\text { Plant } \\
\text { existence }\end{array}$} & \multicolumn{4}{|c|}{ Particle size distribution, \% } & \multirow{2}{*}{ Texture } & \multirow{2}{*}{$\begin{array}{l}\text { Porosity \% } \\
\text { by volume }\end{array}$} & \multicolumn{2}{|c|}{ SWC (\%) Vs. SWP (bar) } \\
\hline & & Course Sand & Fine sand & Silt & Clay & & & 0.33 (FC) & 15 (PWP) \\
\hline \multirow{2}{*}{1} & $\mathrm{C}$ & 42.9 & 41.3 & 10.3 & 5.4 & Loamy sand & 43.7 & 34.58 & 6.66 \\
\hline & $\mathrm{B}$ & 63.4 & 32.5 & 3 & 2.1 & Sand & 29.8 & 16.71 & 3.53 \\
\hline \multirow{2}{*}{2} & $\mathrm{C} 2$ & 35.2 & 45 & 12 & 7.9 & Loamy sand & 42.5 & 31.75 & 6.24 \\
\hline & $\mathrm{B} 2$ & 45.1 & 40.5 & 8.5 & 6 & Loamy sand & 35.2 & 18.07 & 4.26 \\
\hline \multirow{2}{*}{3} & C3 & 28.1 & 41.1 & 18.3 & 12.5 & Sandy loam & 47.9 & 32.53 & 6.37 \\
\hline & B3 & 33.3 & 39.7 & 15.4 & 11.6 & Sandy loam & 44.3 & 28.89 & 7.41 \\
\hline \multirow{2}{*}{4} & $\mathrm{C} 4$ & 31.9 & 38.2 & 16.1 & 13.8 & Sandy loam & 47.5 & 33.96 & 7.02 \\
\hline & B4 & 37.2 & 31.2 & 17.9 & 13.7 & Sandy loam & 46.4 & 33.28 & 9.17 \\
\hline
\end{tabular}

The studied physical parameters were particle size distribution (PSD), total porosity, and soil water content (WC) associated with 0.33 and 15 bar soil water potential (WP) which are representing field capacity (FC) and permanent wilting point (PWP) respectively.. Elbeih et al. (2011) stated that "the suitability of agricultural land-use depends on the availability and quality of the irrigation water". Also, Ibrahim et al. (2010) compared reclaimed soil and cultivated soils (which somehow are closed to soil coved with wild plants) with un-reclaimed one (which somehow is closed to bar soil). The results showed that the reclamation lead to increase the silt and clay contents in the reclaimed soils especially in the surface layers. The results revealed that plant existence increased the variation range of soil moisture content between field capacity and permanent wilting point (PWP) which increase the amount of available water (AW) for plant which assists the plant to grow better especially in desert soil. In this respect, Panchal and Pandey (2002) reported that "Reduction of clay content, water holding capacity, field capacity, organic carbon and available phosphorus exhibited positive correlation with reduction of number of perennial plant species and their density"

The results of PSD, generally, showed that soil texture was slightly finer in plant covered soil than bare one at same location. This may be due to the natural heterogeneity of the texture of the deserts. Also, the plants work as a wind break, so the fine particles that are thrown down at the area of grown plants and the texture started to change year after year. The texture and total porosity strongly affect soil moisture status and may help in explaining the resulting favorable effect of plant existence on WHC and AW of soil.

Soil chemical analysis data of the bare and plant covered soils of the four studied sites are presented in Table 2 .

Table 2: soil chemical analysis of the bare and plant covered soil in the experimental studied sites

\begin{tabular}{|c|c|c|c|c|c|c|c|c|c|c|c|c|}
\hline \multirow[b]{3}{*}{ Site } & \multirow[b]{3}{*}{ plant } & \multirow[b]{3}{*}{$\mathrm{CaCO}_{3} \%$} & \multirow[b]{3}{*}{$\mathrm{EC} \mathrm{ds} / \mathrm{m}$} & \multirow[b]{3}{*}{$\mathrm{pH}$} & \multicolumn{8}{|c|}{ Soluble ions, meq/100 g soil } \\
\hline & & & & & \multicolumn{4}{|c|}{ Cations } & \multicolumn{4}{|c|}{ Anions } \\
\hline & & & & & $\mathrm{Ca}^{2+}$ & $\mathrm{Mg}^{2+}$ & $\mathrm{Na}^{+}$ & $\mathrm{K}^{+}$ & $\mathrm{CO}_{3}{ }^{2-}$ & $\mathrm{HCO}_{3}^{-}$ & $\mathrm{Cl}^{-}$ & $\mathrm{SO}_{4}{ }^{2-}$ \\
\hline \multirow[b]{2}{*}{1} & $\mathrm{C}$ & 5.21 & 7.05 & 7.65 & 39.12 & 19.69 & 18 & 0.79 & 0 & 2.87 & 34.55 & 40.17 \\
\hline & $\mathrm{B}$ & 3.96 & 6.35 & 7.7 & 25.68 & 22.31 & 21.4 & 0.93 & 0 & 4.44 & 38.22 & 27.65 \\
\hline \multirow[b]{2}{*}{2} & $\mathrm{C}$ & 4.1 & 1.6 & 7.65 & 7.85 & 5.34 & 2.22 & 0.67 & 0 & 3.24 & 6.28 & 6.56 \\
\hline & $\mathrm{B}$ & 3.7 & 0.78 & 7.85 & 3.85 & 2.82 & 0.98 & 0.24 & 0 & 1.94 & 1.82 & 4.12 \\
\hline \multirow[b]{2}{*}{3} & $\mathrm{C}$ & 4.45 & 3.28 & 7.55 & 17.85 & 10.15 & 5.72 & 0.68 & 0 & 3.42 & 7.28 & 23.7 \\
\hline & B & 4.95 & 2 & 7.5 & 10.13 & 7.05 & 2.21 & 0.4 & 0 & 2.87 & 3.64 & 13.28 \\
\hline \multirow[b]{2}{*}{4} & $\mathrm{C}$ & 4 & 1.75 & 7.65 & 7.05 & 8.2 & 1.31 & 0.54 & 0 & 6.11 & 5.14 & 7.35 \\
\hline & B & 4.35 & 1.15 & 7.7 & 4.63 & 5.36 & 1.22 & 0.55 & 0 & 2.94 & 4.37 & 4.45 \\
\hline
\end{tabular}

No specific trend of the effect of plant existence on soil chemical analysis was observed except EC. A statistical analysis was performed to ensure the significance of the studied sites and plant existence.

Table 3 represents statistical analysis of selected physical and chemical data for discussion. The chosen parameters were WHC, AW, porosity, EC, and pH. Such selection was done to focus on soil water status and related properties.
Table3: Statistical analysis (ANOVA) of WHC, AW, porosity, EC, and $\mathrm{pH}$ of the plant covered and bare soil at the four studied sites

\begin{tabular}{|c|c|c|c|}
\hline Source of variance & Dependent Variable & $\mathrm{F}$ & Sig. \\
\hline \multirow{4}{*}{ Site } & Porosity & 8.84 & $0.001^{* *}$ \\
\cline { 2 - 4 } & WHC & 3.51 & $0.040^{*}$ \\
\cline { 2 - 4 } & $\mathrm{AW}$ & 8.04 & $0.002^{* *}$ \\
\cline { 2 - 4 } & $\mathrm{EC}$ & 339.82 & $0.000^{* *}$ \\
\cline { 2 - 4 } & $\mathrm{pH}$ & 0.55 & 0.654 \\
\hline \multirow{4}{*}{ Plants existence } & Porosity & 20.07 & $0.000^{* *}$ \\
\cline { 2 - 4 } & WHC & 28.59 & $0.000^{* *}$ \\
\cline { 2 - 4 } & $\mathrm{AW}$ & 76.43 & $0.000^{* *}$ \\
\cline { 2 - 4 } & $\mathrm{EC}$ & 37.83 & $0.000^{* *}$ \\
\cline { 2 - 4 } & $\mathrm{pH}$ & 0.25 & 0.622 \\
\hline
\end{tabular}




\section{International Journal of Science and Research (IJSR) \\ ISSN (Online): 2319-7064}

Index Copernicus Value (2013): 6.14 | Impact Factor (2014): 5.611

The performed statistical analysis showed significant effect of the sites difference on porosity, WHC, AW, and EC and non-significant effect on $\mathrm{pH}$. In other words, the obtained statistical results indicate that there are natural heterogeneity of the studied area of eastern desert, on WHC, AW, and EC. Homogeneity only found with soil $\mathrm{pH}$. Also, significant effect was found between the soils covered with plants and bare one (i.e. wild plants existence effect) on WHC, AW, and EC and non-significant effect on $\mathrm{pH}$. So, it could be concluded that wild plants existence indicates remarkable effect on porosity, WHC, AW, and EC. All sites showed relatively high EC as affected by plants existence compared with bare soil. This is may be due to the selectivity of desert plants such result may be due to the selectivity and ability of wild plants to absorb water only and leave salts behind which raises soil salinity.

Requena et al. (2001) and Lange et al. (2014), in different studies, indicated that there is integral effect of plant species diversity and physical, chemical and biological soil properties (e.g. soil texture, moisture, $\mathrm{pH}$, and microbial activity).

The effect of plants existence on WHC and AW, which is the main focus of the study, are presented in separate figure (Fig. 1). Furthermore, significant combined effect (i.e. interaction) of both sites and plants existence on porosity, WHC and AW and non-significant effect on EC and $\mathrm{pH}$. The significant effect may be related to that there is special effect of the sites properties of naturally grown plants, which is revealed in huge diversity of existed plants and seeds, as indicated by ElAmier and Abdul-Kader (2015) Gomaa (2012).

Fig 1 shows the measured soil water parameters (WHC and AW) as affected by plants existence (i.e. at plant covered and bare soils) in the four studied sites.

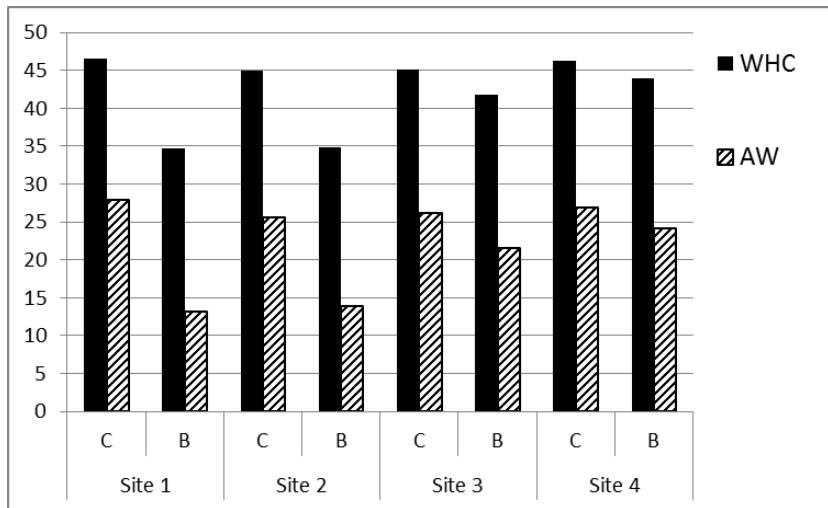

Figure 1: Effect of plant existence on WHC and AW in four sites

Figure 1 indicates that both WHC and AW were changed and improved in plant covered soil comparing to bare soil. WHC, which reflects the ability of the soil to hold and retain water and save it from deep seepage losses, was increased from 34.68 to $46.61,34.91$ to $44.95,41.76$ to 45.14 and 43.97 to 46.22 for bare soil comparing to plant covered soil for the four studied sites, respectively. Fig 1 reveals that WHC was higher under plant covered soil than bare soil. Also, soil water availability is another very important factor limiting reclaiming and cultivating desert soils.

So the research mainly focuses on soil water availability, which represents the range of water that the plant can uptake or absorb from soil. The wider of available water the wider irrigation interval allowance, which reflects better soil productivity. Furthermore, the irrigation wide interval helps the grower to reduce cost and to face unexpected water deficit. AW was increased from 13.18 to 27.92, 13.81 to 25.51, 21.48 to 26.16 and 24.12 to 26.94 for bare soil comparing to plant covered soil for the four studied sites, respectively. Increasing WHC and AW is very important especially in deserts where water is scarce and is considered the limiting factor for reclamation and cultivation. These results could be explained by the beneficial effect of the interaction between plant roots and soil physical properties. In this respect, El-Amier and Abdul-Kader (2015) indicated that: soil physical properties were one of the main driving factors controlling the distribution of wild plants in the northern sector of Eastern Desert. Furthermore, Lei Deng et al. (2014) stated that "fencing significantly influenced soil bulk density (BD) and moisture content (SW)".

\section{Conclusion and Recommendations}

It could be concluded that, existence of plant cover improved soil water holding capacity and available water. The study recommended reclaiming the areas of desert covered with wild or naturally grown plants to be used in producing economic crops because of its favorable effect on soil water status alongside bare soil. Further studies are required for wider desert sites and different soil textures to ensure and generalize the obtained results. Also, further studies are needed to show if there is special effect of individual plant or group of plants to make sure which area should take more attention and priority for.

\section{References}

[1] M. Abd El-Ghani, M. Abo El-Kheir, M.S. AbdelDayem, M. Abd El-Hamid, "Vegetation analysis and soil Characteristics of five common desert climbing plants in Egypt," Turkish Journal Of Botany, Vol.35(5), pp.561-580, 2011.

[2] C. A. Black, "Method of Soil Analysis," Part 2, Chemical and Microbiological Properties, American Society of Agronomy, Inc, Publisher, Madison, Wisconsin USA, 1965

[3] Y.A. El-Amier , O.M. Abdul-Kader, "Vegetation and Species Diversity in the Northern Sector of Eastern Desert of Egypt," West African Journal of Applied Ecology, vol. 23(1), pp. 75-95, 2015.

[4] P. Zdruli, "Desertification in the Mediterranean Area,". European Institute of the Mediterranean (IEMed): Barcelona; pp. 250-254, 2011.

[5] S.F. Elbeih, A.B. Belal, A. El-Sayed, E.A. Zaghloul, "Hazards mitigation and natural resources evaluation around Sohag - Safaga highway, Eastern Desert, Egypt," Egyptian Journal of Remote sensing and Space Sci., Vol. 14 (1), pp. 15-28, 2011. 
[6] N.H. Gomma," Soil seed bank in different habitats of the Eastern Desert of Egypt," Saudi J Biol. Sci. Apr. 19(2), pp. 211-220, 2012.

[7] A.M. Hegazi, M.Y. Afifi, M.A. EL Shorbagy, A.A. Elwan, S. El- Demerdashe, "Egyptian National Action Program To Combat Desertification," Ministry of Agriculture and Land Reclamation Desert Research Center, Egypt 2005.

[8] M.S. Ibrahim, M.H. Ali, M.M. Kotb, "Soil Properties as Affected by Different Land Management Practices in the Sohag Region, South Egypt," New York Science Journal, Vol. 3 (7), pp. 8-19, 2010.

[9] M.L. Jackson, Soil Chemical Analysis, Englewood Cliffs N.J. Prentice Hall. Inc., 1964.

[10] A. Klute, Methods of Soil Analysis, Part-1: Physical and Mineralogical Methods 2nded, A. Madison Wisconsin, U.S.A., 1986.

[11] M. Lange, M. Habekost, N. Eisenhauer, C. Roscher, H. Bessler, C. Engels, Y. Oelmann, S. Scheu, W. Wilcke, E. Schulze, G. Gleixner, "Biotic and Abiotic Properties Mediating Plant Diversity Effects on Soil Microbial Communities in an Experimental Grassland," Plos one vol. 9 (5), pp. 1-9, 2014.

[12] L. Deng, Z. Zhang, Z. Shangguan, "Long-term fencing effects on plant diversity and soil properties in China," Soil and Tillage Research, Vol. (137), pp. 7-15, 2014.

[13] A.L. Page; R.H. Miller, D.R. Keeney, Methods of Soil Analysis, Part 2, 2ndEd, Am. Soc. Agronomy, Inc. Mad. Wisconsin, USA, 1982.

[14] N.S Panchal, A.N. Pandey, "Study on Soil Properties and Their Influence on Vegetation in Western Region of Gujarat State in India," $12^{\text {th }}$ ISCO Conference Beijing China, pp. 610-615, 2002.

[15] C.S. Piper, Soil and Plant Analysis, Interscience Publishers Inc, Inkata Press New York, 1947.

[16] N. Requena, E. Pérez-Solis, C. Azcon-Aguilar, P. Jeffries, J.M. Barea, "Management of indigenous plantmicrobe symbioses aids restoration of desertified," ecosystems Appl. Environ. Microbiol, Vol. 67, pp 495498, 2001.

[17] D.A. Skoog, D.M. West, F.J. Holler, Fundamentals of Analytical Chemistry, 7th Edition, Thomson Learning Inc, USA, 1996.

[18] A.A. Yousef, A.E. Hegazi, "Security impacts of desertification in Egypt," In Kepner, W.G., Rubio,J.L., Mouat, D.A., and Pedrazzini, F. (eds.). Desertification in the Mediterranean Region: A Security Issue, Valencia NATO Workshop, Springer, pp. 187-199, 2006.

\section{Author Profile}

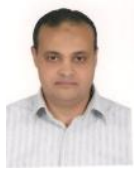

Wail Omran received the B.S., M.S. and $\mathrm{PhD}$ degrees in Agricultural Science (i.e. Soil Science) from Department of Soil Science, Faculty of Agriculture, Menofia University in 1989, 1994 and 2001, respectively. Professional Career was as follows: Demonstrator - Assistant Lecturer - Lecturer - Associate Professor in Faculty of Agriculture, Menofia University. During 1997-1999, he stayed in Bio-systems Engineering Department, University of Hawaii, USA, to collect Scientific data required for his $\mathrm{PhD}$. Research Interest were using soil amendments and conditioners to improve poor and new reclaimed soils; soil water characteristic curve; salinity and drought stresses. 